\title{
Front Matter: Volume 11744
}

, "Front Matter: Volume 11744," Proc. SPIE 11744, Laser Radar Technology and Applications XXVI, 1174401 (30 April 2021); doi: 10.1117/12.2598582

SPIE. Event: SPIE Defense + Commercial Sensing, 2021, Online Only 


\section{PROCEEDINGS OF SPIE}

\section{Laser Radar Technology and Applications XXVI}

Monte D. Turner

Gary W. Kamerman

Editors

12-16 April 2021

Online Only, United States

Sponsored and Published by

SPIE 
The papers in this volume were part of the technical conference cited on the cover and title page. Papers were selected and subject to review by the editors and conference program committee. Some conference presentations may not be available for publication. Additional papers and presentation recordings may be available online in the SPIE Digital Library at SPIEDigitalLibrary.org.

The papers reflect the work and thoughts of the authors and are published herein as submitted. The publisher is not responsible for the validity of the information or for any outcomes resulting from reliance thereon.

Please use the following format to cite material from these proceedings:

Author(s), "Title of Paper," in Laser Radar Technology and Applications XXVI, edited by Monte D. Turner, Gary W. Kamerman, Proc. of SPIE 11744, Seven-digit Article CID Number (DD/MM/YYYY); (DOI URL).

ISSN: 0277-786X

ISSN: 1996-756X (electronic)

ISBN: 9781510643253

ISBN: 9781510643260 (electronic)

Published by

SPIE

P.O. Box 10, Bellingham, Washington 98227-0010 USA

Telephone +1 3606763290 (Pacific Time)

SPIE.org

Copyright @ 2021 Society of Photo-Optical Instrumentation Engineers (SPIE).

Copying of material in this book for internal or personal use, or for the internal or personal use of specific clients, beyond the fair use provisions granted by the U.S. Copyright Law is authorized by SPIE subject to payment of fees. To obtain permission to use and share articles in this volume, visit Copyright Clearance Center at copyright.com. Other copying for republication, resale, advertising or promotion, or any form of systematic or multiple reproduction of any material in this book is prohibited except with permission in writing from the publisher.

Printed in the United States of America by Curran Associates, Inc., under license from SPIE.

Publication of record for individual papers is online in the SPIE Digital Library.

\section{SPIE. DIGITAL}

Paper Numbering: A unique citation identifier (CID) number is assigned to each article in the Proceedings of SPIE at the time of publication. Utilization of CIDs allows articles to be fully citable as soon as they are published online, and connects the same identifier to all online and print versions of the publication. SPIE uses a seven-digit CID article numbering system structured as follows:

- The first five digits correspond to the SPIE volume number.

- The last two digits indicate publication order within the volume using a Base 36 numbering system employing both numerals and letters. These two-number sets start with $00,01,02,03,04$, 05, 06, 07, 08, 09, 0A, OB ... 0Z, followed by 10-1Z, 20-2Z, etc. The CID Number appears on each page of the manuscript. 


\section{Contents}

NOVEL LIDAR SENSING APPLICATIONS

$1174403 \quad$ Using principle component analysis to estimate geometric parameters from point cloud LIDAR data [11744-2]

1174404 Extraction of precise object orientation and position from LIDAR data using maximumlikelihood methods [11744-3]

\section{BATHMETRY AND ATMOSPHERICS}

1174406 Simulation and optimization-based method of environmental parameter distribution from airborne bathymetric LIDAR data [11744-5]

\section{LASER AND SYSTEM COMPONENT ADVANCEMENTS}

$11744 \mathrm{OB}$ Thermal drift compensation in dark-frame non-uniformity correction for an InGaAs PIN 3D flash lidar camera [11744-10]

11744 OC In-situ proton radiation testing of 2.4 micron wavelength extended InGaAs photodiodes at dry ice and room temperatures [11744-11]

11744 OD Maturation of a single frequency ErYAG laser for water vapor/methane DIAL application [11744-12]

11744 OF Range-compensating lens design, implementation and experimental results [11744-18]

\section{ADVANCED AIR/GROUND LIDAR SYSTEMS AND USE}

11744 OG Random field models for spatial smoothing of airborne lidar transect data [11744-14]

11744 0l Compact laser altimeter dedicated to drone ballistic carriers [11744-16]

$117440 \mathrm{~J} \quad$ Land movement detection from terrestrial laser scanner (LiDAR) analysis [11744-17] 
Proc. of SPIE Vol. 11744 1174401-4 Downloaded From: https://www.spiedigitallibrary.org/conference-proceedings-of-spie on 26 Apr 2023
Terms of Use: https://www.spiedigitallibrary.org/terms-of-use 